\title{
THE EFFECTIVENESS OF EDUCATIONAL SUPERVISION IN COVID-19 PANDEMIC ERA
}

\author{
Siti Sanisah', Abdul Kadir ${ }^{2}$, Lukman ${ }^{3}$, Edi $^{4}$ \\ ${ }^{1}$ Geography Education, Muhammadiyah University of Mataram \\ ${ }^{234}$ English Education, Muhammadiyah University of Mataram \\ sitisanisah25@gmail.com
}

\begin{abstract}
This survey aims to determine the effectiveness of educational supervision during the Covid-19 pandemic era. The survey was conducted in two different locations/districts: Central Lombok and East Lombok, involving 250 educators who were chosen randomly. The focuses in this survey are three important aspects of educational supervision: supervisors' supervision, supervisor's attendance level, and the directions function given to educators and education staff. The survey results concluded that supervision at schools was carried out internally and externally with varied levels of supervisor attendance to provide direction to educators and education staff. The frequency of attendance of the internal supervisor (Principal) is considered more intense $(71 \%)$ than other supervisors. Likewise, the directions given are considered more useful by $85 \%$ of respondents than the directions given by other supervisors. The supervisors are expected to work even more optimally and provide constructive and relevant directions to the existing situation and conditions to maximize the supervision.
\end{abstract}

Keywords: Education Supervision, Pandemic Era, Covid-19,

\section{INTRODUCTION}

The covid-19 pandemic is not only a catastrophic disaster that impacts economic and people movement. The pandemic is also a serious challenge for educational staff, especially the School Supervisors. An adagio to "stay at home" with "keep working" becomes important to be discussed. School cannot wait. Educational supervisors, principals, teachers and students remain healthy, but education must continue to achieve its goals and visions. If this synergy continues and this pandemic ends, it will produce school supervisors, principals, teachers, and new era students familiar with the digital era, for example.

The supervisors' competency is utterly required to have: personality, managerial supervision, academic supervision, educational evaluation, 
research and development. These requirements have become a challenge for all supervisors, either internal or external. The supervisor serves as an activator for educators to stay healthy, safe and keep working in any situation, especially in the Covid-19 pandemic. In a Covid-19 pandemic where they are required to work from home, school supervisors must continue to carry out their duties to guide teachers, principals, and institutions.

The supervision implementation in some schools, especially in Central Lombok and East Lombok Districts, often encounter obstacles, especially during the covid-19 pandemic. Due to the presence of less prepared supervisors, experience during the supervisor's functional training has not been sufficient provision to carry out supervisory duties, lacking awareness to supervisor's responsibility and attitudes and impressions, teachers who are not entirely open to supervisors make supervision less effective (Nurmala et al. 2019). Initial research showed that the presence of external supervisors was lower in frequency. It seemed not much different from their roles in giving advice, controlling, recuring the problems schools, principals or teachers and other components at school (Syafrudin, an interview on Thursday, $4^{\text {th }}$ of November 2021).

Based on this background, the author examines in-depth research on the effectiveness of supervision in the Pandemic Era in two districts (Central Lombok and East Lombok). Specifically, the purpose of this study was to find out three important aspects of educational supervision: supervision in the schools, the supervisor's attendance level and the directions function given by supervisors to educators and education staff. With this presentation, this study can provide information to reflect the application of educational supervision during the Covid-19 pandemic.

\section{LITERATURE REVIEW}

One of the four functions of management is controlling (supervision or control). This control ensures that every work is carried out corresponding to 
what was previously planned (Agindawati, 2019; Dakhi, 2016). If the system causes discrepancies, some corrections must be made by reviewing the plan. It means that the supervisory function as a corrective effort must be used properly as a steppingstone to determine whether the previously determined plan needs to be continued, revised, or may even be replaced with a new one and of course, it is supposed to be finished after seeing the results of the existing works.

The important matter during the control process is that the controller focuses on the outcome, behavior, and clan (Han et al., 2019; Kirsch, 1996; Sihag \& Rijsdijk, 2019). Firstly, outcome control refers to a review of completed activities that are carried out and provided feedback so that corrective action can be taken or further improvements can be made (Kirsch, 1996). Secondly, behavior control that the controller emphasizes the importance of procedures and rules for the sake of the controlled persons will be followed when carrying out their duties (Liu \& Wang, 2016; Sihag \& Rijsdijk, 2019). Thirdly, clan control refers to the controller's mechanisms to ensure that the controlled person embraces shared values and goals and is committed to a common goal (Sihag \& Rijsdijk, 2019).

Supervision is an important part of the implementation and improvement of education. This section is the evaluation stage through a series of activities to supervise, check, match, and control all educational activities to conform to the established plan and the desired results (Rahmah, 2018; Sudjana, 2009). Ideally, effective supervision is carried out by competent parties through systematic and well-planned stages with proportional targets (Rahmah, 2018). Effective supervision can help the academic unit to organize the planned work so that its implementation runs smoothly and is completed properly. The supervisory effectiveness can be observed through the supervisor's performance in carrying out three main activities, e.g., measuring work results, comparing work results with 
standards, and correcting unwanted deviations through corrective actions (Stoner, 1996).

In carrying out their duties and functions, supervisors determine the methods to be used, such as pre-action control, steering control, screening control and post-action control (Stoner \& Freeman, 2010). Pre-action control is carried out to ensure that all resources in an activity are ready to avoid other new problems. Steering control is formatted to detect deviations from predetermined goals or standards. Such action allows improvements to be made to an activity before completing the activity. Screening control is a screening process where certain aspects and conditions must be met before the activity proceed. Meanwhile, post-action control is to measure the results of actions that have been implemented.

Supervision carried out on schools is a systemic effort to obtain an overview of the overall education program implementation leading to improving the quality of schools and education (Abunifah, 2014; Rahmah, 2018). This provision applies comprehensively to all academic units such as Islamic boarding schools, madrasas, and other educational institutions. Thus, the supervisory function in the education unit is very important. Unless, all parties who act as supervisors must understand the tasks, steps and supervision strategies that will be carried out so that the roles can be carried out properly and usefully.

School's supervision is just like supervising any other work organization that can be carried out by internal and external parties (Modo, 2020; Nurmayani, 2014). Internal supervision is the school's supervision carried out by people or supervisors in the school environment concerned. This form of supervision can be carried out using built-in control (direct supervisor supervision or attached supervision). At the same time, external supervision is supervision carried out to the schools by other supervisory units outside the supervised school unit. 
In school development, supervisors have a role in supervising several aspects, e.g., curriculum and learning, students, facilities and infrastructure, personnel, finance, school relations with the community and special services. (Abunifah, 2014; Sudibyo, 2007). Thus, supervisors act as managerial and academic supervisors. The task as an academic supervisor is to assist teachers in developing their professional abilities to improve the learning quality (Rahmah, 2018; Slameto, 2016).

In the era of the Covid-19 pandemic, surveillance practices are still carried out, although in a different way than before. The supervisory approach has also experienced a shift by using available media, such as Google forms and other online applications (Saleh, 2021; Sugiyono, 2021), although there are still many supervisors who make visits to schools but by implementing health protocols strictly (Aspandi, 2020; Sarjono, 2020; Sugiyono, 2021).

In general, supervision activities are carried out to improve the learning quality, which can be done through in-service education activities (Olivia, 1984). This activity is very useful for coordinating, stimulating, and directing the growth and development of teacher abilities, expanding teacher experience, and stimulating creative efforts. In addition, it can also provide continuous facilities and assessments, analyze learning situations, transfer knowledge to teachers and staff, integrate educational goals and help improve teacher competencies (Modo, 2020).

Principally, there is no reason for supervisors not to carry out surveillance activities even though they are in the middle of a pandemic. The research supported this result, proving that supervision significantly improves teacher performance (Hazli \& Saputra, 2019; Ramadhan, 2017) and professionalism (Messi et al., 2018). Supervision that is carried out properly and structured also has a positive impact on the teacher's independent work ethic (Chadijah, 2019), improving the quality of school management (Abunifah, 2014) and education in general (Rahmah, 2018). 


\section{METHODOLOGY}

This research is a qualitative descriptive study that seeks to explain all phenomena in research settings (Alwi, 2009). The study used a survey technique (Anugrahana, 2020; Fadilla et al., 2021) which was carried out directly by meeting the teacher at the workplace (school) and then filling in a questionnaire, conducting in-depth interviews, and observations. The last two activities were carried out to strengthen the information provided by respondents through a questionnaire. Data were obtained from the research subjects, namely 250 teachers ( $72 \%$ female and $28 \%$ male). Most of the respondents (161) are honorary teachers, and the rest are civil servant teachers or PPPK (Government Employees with Work Agreements).

For ensuring the validity of the research data, credibility, dependability, confirmability and transferability tests were carried out (Sanisah, 2015). Furthermore, the data obtained from the field was processed using the KoboToolbox and analyzed using a qualitative data analysis approach from Miles and Huberman, which consisted of three important stages, i.e., data collection, data reduction, presentation, and verification (Miles \& Huberman, 1992).

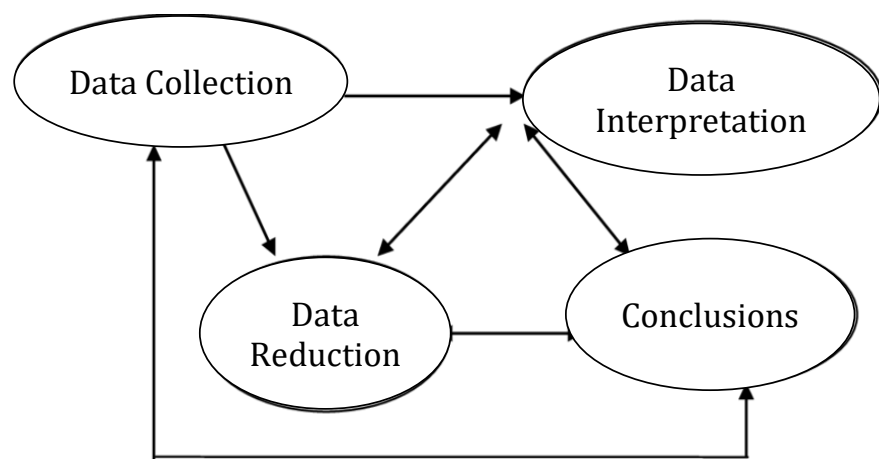

Figure 1. Steps of Data Analysis According to Miles and Huberman

\section{RESULTS AND INTERPRETATION}


Ideally, supervision is carried out by a competent party through systematic and well-planned stages with proportional targets. The supervision carried out in the education unit is directed to obtain an overview of the education program's overall implementation, which leads to quality improvement. This provision applies to all academic units, both schools (Islamic boarding schools and madrasah), and other educational institutions. It means that the supervisory function in the education unit is very important. For this reason, those who act as supervisors must understand the tasks, steps and supervision strategies so that the duty can be carried out properly and proportionally.

Since the Covid-19 pandemic continues, the implementation of supervisory duties and functions is increasingly complex with online learning. Although there are restrictions on face-to-face learning (even abolished within a certain period), supervision is still important to carry out. Especially to ensure that learning is carried out properly during the pandemic, obeying health protocols and other directives from the local government or other authorized parties. It also means that they must remain to monitor the learning process.

\section{The Existence of Supervisors in Schools}

The supervisors' presence at the survey location is not much different before and during the pandemic. Supervision is still carried out intensively by internal and external supervisors (Modo, 2020; Nurmayani, 2014). Internal supervisors consist of principals, vice-principals and senior teachers who are deemed eligible (having a higher rank and tenure than other teachers) to run supervision around the school environment. Meanwhile, external supervisors are supervisors who come from outside of the institution (school). External supervisors generally come from the Education Office (for schools under the Ministry of Education and Culture), the Ministry of Religion (for religionbased schools and under the Ministry of Religion), and the School Committee. 
External supervisors can also come from different institutions, which carry out supervisory duties with specific objectives and are approved by the competent authorities.

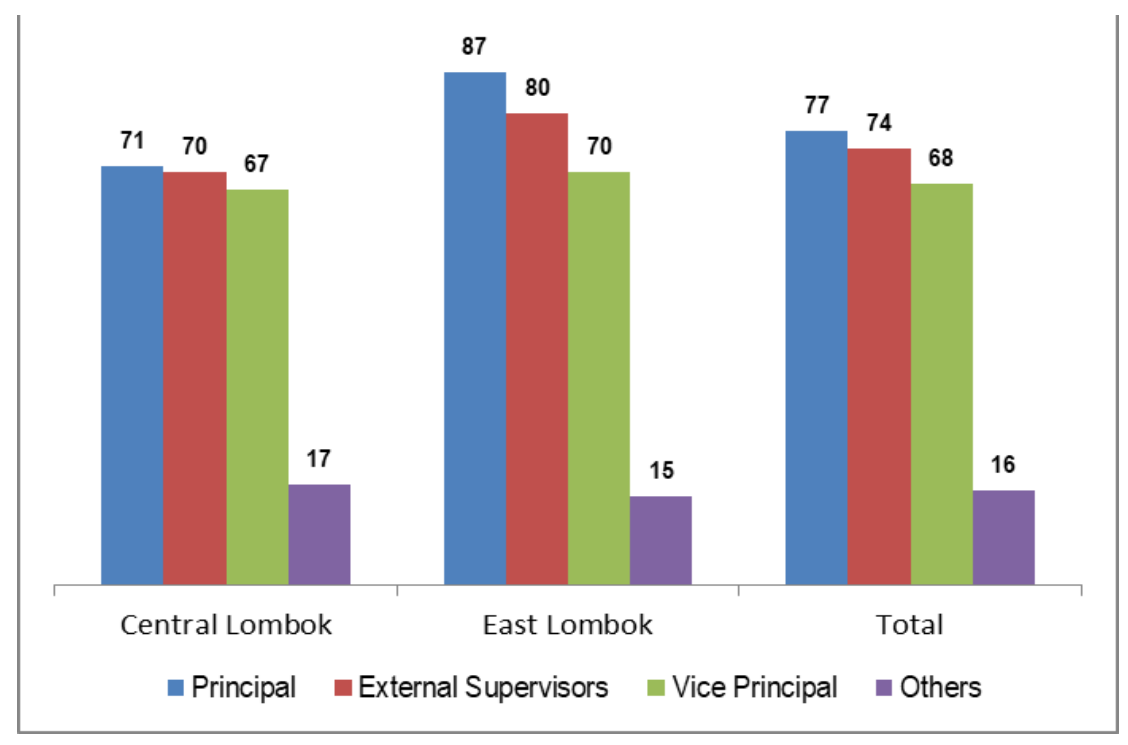

Figure 2. The Percentages of The Existence of School Supervisor

The internal supervisors' presence in schools was enough to carry out their supervisory duties and functions, especially for school principals, considering the percentage of teachers' presence is quite high in the two survey locations. In general, the presence of school principals reaches $77 \%$, meaning that although they are considered adequate, however, still, there are $23 \%$ of respondents who say otherwise. The principal presence in carrying out the supervision duties and functions in schools needs to be maximized again. Given that one of the principal's roles is as a supervisor, he has full responsibility and authority to supervise teachers in his school (Guntoro, 2020; Hazli \& Saputra, 2019; Nurfatah \& Rahmad, 2018).

As an extension of the school's headmaster, the vice-principal can also carry out supervisory actions based on his position as Deputy Head of School and principal representative. In fact, in carrying out supervisory duties, the principal often delegates the task to the deputy principal or other teachers considered seniors (judging by the tenure and rank). This finding is known 
from in-depth interviews conducted by the writer. Under these conditions, the vice principal performs a dual role in supervision. In order to minimize the centralization of supervisory duties on the vice-principal and avoid overlapping duties and functions, principals should be able to empower senior teachers to carry out supervisory duties in the format of peer supervision (Hadi \& Nasuka, 2019). However, only 5\% of principals do so.

Furthermore, the percentage of schools' supervisors is higher in East Lombok Regency than in Central Lombok Regency, both for internal and external supervisors (Department of Education and the local Ministry of Religion). However, their presence in Central Lombok Regency is higher for other external supervisors than in East Lombok Regency. The average of other external supervision was $16 \%$, which shows that the involvement of other elements in the learning supervision in the schools before and during the pandemic is still low. In regulations, the space to support and carry out supervision from stakeholders on implementing education in schools is widely open (Darmadji, 2003). Article 8 of the National Education System Act states that the community has the right to participate in the planning, implementation, monitoring and evaluation of educational programs (Nasional, 1982).

The difference between supervisors at educational institutions before and during the pandemic is the increasingly diverse representatives of institutions that carry out supervision as external supervisors, while the elements of internal supervisors have not changed. Apart from the Education Office and the local Ministry of Religion, the institutions in question also come from the Village Government, Health Service, police, and elements of the Army. The supervision is carried out with a different purpose: to ensure that all elements in the school carry out activities and learning while still prioritizing health protocols to contain the Covid-19 outbreak (LPPKSPS, 2020). Generally, the external supervisors' presence has been determined 
through government policy (central or regional through the Education Office).

\section{Presence of Supervisors at School}

According to teachers, the principal is the most frequent supervisor attending schools with the highest percentage (always and often categories). This finding is the same in the two survey districts with insignificant differences. Teachers rate the principal presence in the context of supervision as lower in East Lombok Regency (73\%), a difference of 5\% from the attendance rate of the principal in Central Lombok Regency. In general, the principal's presence was not maximally frequent in the context of supervision, considering that only $71 \%$ of respondents stated their agreement. There are still 29\% of respondents who expressed their disapproval of this condition. Considering the supervisory role by the principal is more dominantly carried out by the deputy principal.

Table 1. Frequency of Supervisory Attendance at School

\begin{tabular}{lccc}
\hline Frequency of Attendance & $\begin{array}{c}\text { Central Lombok } \\
(\mathbf{n = 1 2 5})\end{array}$ & $\begin{array}{c}\text { East Lombok } \\
(\mathbf{n = 1 2 5})\end{array}$ & $\begin{array}{c}\text { Total } \\
(\mathbf{n = 1 5 0})\end{array}$ \\
\hline Principal & & & \\
Never & $9 \%$ & $11 \%$ & $10 \%$ \\
Sometimes & $18 \%$ & $21 \%$ & $19 \%$ \\
Often & $51 \%$ & $49 \%$ & $50 \%$ \\
Always & $22 \%$ & $19 \%$ & $21 \%$ \\
External Supervisors & & & \\
Never & $5 \%$ & $10 \%$ & $7 \%$ \\
Sometimes & $40 \%$ & $51 \%$ & $44 \%$ \\
Often & $46 \%$ & $31 \%$ & $40 \%$ \\
Always & $9 \%$ & $8 \%$ & $9 \%$ \\
Vice Principal & & & \\
Never & $15 \%$ & $21 \%$ & $17 \%$ \\
Sometimes & $35 \%$ & $35 \%$ & $35 \%$ \\
Often & $40 \%$ & $32 \%$ & $37 \%$ \\
Always & $10 \%$ & $12 \%$ & $11 \%$ \\
\hline
\end{tabular}


The teacher's response to supervisory supervisors from the local Education Office or MoRA was different. In general, the attendance rate of supervisors from this element is $49 \%$, or in Central Lombok Regency, it is $55 \%$, and in East Lombok, it is only 39\%. The majority of teachers (44\%) claimed that supervisors from this element were present occasionally. The supervisory function carried out by the Deputy Principal was also not much different. The attendance level is considered intense (often and always) only by $48 \%$ of respondents. Meanwhile, the frequency of other supervisors attendance was recognized by $33 \%$ of respondents.

The study results also illustrated that some supervisors are still considered to have never been presented to carry out supervisory duties at school. The highest percentages for this case were the absence of the deputy principal at $17 \%$, the principal at $10 \%$ and the supervisory supervisor from the Offices (Education and Ministry of Religion) at 7\%. Meanwhile, the absence rate of other supervisors was assessed by $47 \%$ of respondents. The absence of supervisors indicates the supervisors' unprofessionalism in carrying out their duties and can be one of the causes of the low quality of national education (Suhardan, 2007). The basic reason for this occurrence is that supervisors are time-consuming to carry out administrative tasks that require around $65 \%$ to $80 \%$ of the total working time (Suhardan, 2007) and increase their competence (U-Sayee \& Adomako, 2021).

The presence of supervisors at schools can trigger an increase in the work ethic of principals and teachers (Slameto, 2016). In addition, active communication between supervisors and teachers and school principals during coaching also assists them in carrying out their activities (Modo, 2020).

Based on the results of the observation of the school conditions, the principal absence in carrying out supervisory duties and functions has an impact on (1) the inactivity of teachers in giving lessons because teachers feel no one is monitoring their activities; (2) did not know the school's dynamics 
during the absence of the principal: (3) the principal lacked information about the general development of the school; (4) provide a destructive example of the development of a culture of discipline in schools and (5) it potentially triggers teachers' distrust to the principal to improve the school. The inherent supervision carried out by the principal and deputy principal has a significant influence on improving teacher performance (Kurnia Utama et al., 2014).

In general, the supervisor's attendance rate needs to be optimized again, especially during the Covid-19 pandemic, where all education managers in schools need to be fostered and guided more intensely. It is also intended that the implementation of supervisory duties and functions in education is carried out properly and responsibly and provides maximum benefits for improving the quality of education.

\section{Level of Usefulness of Supervisor's Directions}

Optimal implementation of supervisory roles and functions (internal and external) benefits all elements of education (Kurnia Utama et al., 2014; Modo, 2020; Oghuvbu, 2007; Slameto, 2016). Meanwhile, the results showed that the usefulness of the directions given by the supervisor was assessed differently by the respondents.

Table 2 Benefits of Supervisory Directions

\begin{tabular}{lccc}
\hline \multicolumn{1}{c}{ Types of Supervisory } & $\begin{array}{c}\text { Central Lombok } \\
\text { (n=125) }\end{array}$ & $\begin{array}{c}\text { East Lombok } \\
\text { (n=125) }\end{array}$ & $\begin{array}{c}\text { Final } \\
\text { (n=250) }\end{array}$ \\
\hline Principal & & & \\
Very important & $44 \%$ & $51 \%$ & $47 \%$ \\
Important & $37 \%$ & $39 \%$ & $38 \%$ \\
Important enough & $14 \%$ & $4 \%$ & $10 \%$ \\
Not important & $5 \%$ & $6 \%$ & $5 \%$ \\
External Supervisor & & & \\
Very important & $40 \%$ & $43 \%$ & $41 \%$ \\
Important & $42 \%$ & $46 \%$ & $44 \%$ \\
Important enough & $12 \%$ & $5 \%$ & $9 \%$ \\
Not important & $6 \%$ & $6 \%$ & $6 \%$ \\
\hline
\end{tabular}




\begin{tabular}{llll}
\hline Vice Principal & & & \\
Very important & $29 \%$ & $30 \%$ & $30 \%$ \\
Important & $37 \%$ & $44 \%$ & $40 \%$ \\
Important enough & $19 \%$ & $12 \%$ & $17 \%$ \\
Not important & $14 \%$ & $14 \%$ & $14 \%$ \\
\hline
\end{tabular}

In general, respondents rate positively the direction given by the supervisor. As many as $85 \%$ of respondents stated that the suggestions or directions given by the school principal and service supervisor were in a very important and important category. For the same category, respondents' assessment of the direction of the vice-principal only reached $70 \%$ of the respondents. Not many respondents considered that the supervisor's direction was quite useful. The difference in perceptions between teachers in Central Lombok and East Lombok in the context of the usefulness of the supervisor's direction is not too startling.

The dominant directives that were responded as lacking and useless were the directions given by the vice-principal (14\%), followed by directions from the service supervisor (6\%) and directions from the principal (5\%). The teachers tend to ignore the supervisor's direction so that the results are far from expectations. It happens because the supervisors' presence is considered a scourge, often being superior, imposing their will, finding fault with them, and appearing arrogant. This condition makes teachers feel inferior and helpless, so that it has an impact on the reluctance of teachers to develop their creativity (Hadi \& Nasuka, 2019). Teachers also become more stressed and nervous when supervisors come to visit schools (Suhardan, 2007).

On the other hand, the supervision activities carried out are also dominantly oriented to administrative aspects, focusing on physical or material things that are easily observed and neglecting to learn (Suhardan, 2007). Learning is the core of educational activities; supervision is said to be unprofessional and ineffective in improving the quality of education if they still do not make learning the focus. It is believed to be one of the causes of 
the decline in the quality of learning in schools. The logical implication will certainly lead to the low quality of national education.

Indeed, supervision is designed to maximize teaching and learning practices in schools. So that ineffective supervision can create a nonconducive school climate, lack of teacher preparation in learning and the development of students and teachers' misbehavior. Therefore, this condition will affect school discipline, student learning participation in class and teacher performance. The determinants that have the potential to arise in this condition are the occurrence of malpractice among teachers and students during exams, high dropout rates, high rates of student transfer from one school to another (even without a transfer certificate), the occurrence of illegal levies by the school and also by senior students to juniors, the chaotic school environment and the stark difference in professional levels between teachers and principals (Oghuvbu, 2007).

Educational supervision carried out effectively (especially by the principal) will bring teachers and students to activities accordingly, in a neat and proper school environment and school climate, teachers and students discipline, positive and friendly relationships among students-all elements of the school (Oghuvbu, 2007). Teacher administration potentially becomes tidier, supported by positive school regulations, and directed toward achieving school goals and education in general.

In order to support and facilitate these achievements, the Education Office should appoint competent supervisors and principals who can focus more attention on effective teaching and learning activities in schools (Oghuvbu, 2007). In addition to encouraging teacher performance, school principals must also provide adequate educational facilities so that learning activities are effective (U-Sayee \& Adomako, 2021). Thus, supervision in developing the quality of teachers and students can run holistically, which ultimately refers to improving the quality of education. As the front line in producing generations, teachers must be open to receiving directions from 
supervisors to improve performance abilities in the teaching and learning process, personal competence, pedagogical, professional, social and career positions (Guntoro, 2020).

Research also proves that nowadays (pandemic period), there is a shift in information and the focus of guidance carried out by supervisors. The information submitted to the school by the supervisory supervisor, including the teacher by the principal of the dominant school, is related to the pandemic issue. Other external supervisors also do the same thing so that education and learning issues become secondary information.

The focus of the supervisor's direction before the pandemic was dominant towards the completeness and availability of learning administration owned by the teacher, the activeness of students and teachers in learning and general learning conditions. In the pandemic, the focus was different and more intense directed towards continuous learning even though it was in an alarming atmosphere due to the pandemic. So, supervisors have repeatedly said the need for a joint commitment to breaking the Covid-19 chain while still holding onto the overall health protocol.

Concerning learning activities in general during the pandemic, it is known that supervisors only carry out monitoring to determine the level of learning activity. It does not provide focused assistance to teachers on ways and techniques of conducting online learning, especially those related to learning using applications. By the principal, teachers are directed to learn independently about the use of IT in online learning and free teachers to use the desired application, with the condition that the application is easy, safe, and comfortable to use and familiar to students, teachers and guardians of students. 


\section{CONCLUSION}

The Covid-19 pandemic has not hampered the attendance of supervisors to academic units. Supervision carried out by school principals, school/madrasah supervisors, vice-principals, and other teachers are still carried out periodically. The quantity of supervision carried out by school principals is more intense than other supervisors, and also, the directives were given are much higher than those given by internal supervisors and vice-principals/madrasahs. It is undeniable that adequate supervision is a sine-qua-non for achieving effective and efficient teaching and learning in schools, both externally and internally.

For this reason, to achieve the educational and learning objectives that have been set, it is hoped that supervisors in the education unit to carry out supervision and guidance can be even more intense. Coaching for teachers is more focused on implementing learning and learning without leaving other aspects of coaching. The Education Office and schools must also make various efforts to supervise teacher performance and learning activities in general. For this reason, supervision in the context of coaching teachers can be carried out by (1) guiding teachers who have not yet continued to improve their competencies; (2) increasing the minimum standard of the teacher teaching success through daily coaching and in-service training; (3) continuous development of problem-solving skills for each teacher; (4) create networking with various teacher working groups to broaden the teachers' knowledge related to education and learning; (5) together with the teacher, revise the school curriculum so that it is more focused to meet what students' needed and (6) always on the track towards meeting optimal educational standards.

\section{REFERENCE}

Abunifah. (2014). Peranan Pengawas Sekolah Dalam Meningkatkan Mutu Pengelolaan Sekolah. Jurnal Pendidikan Dan Kepengawasan, 2(2). 
Agindawati, I. N. (2019). Implementasi Kebijakan Publik dari Perspektif Penyelenggaraan Pengawasan. Jurnal Inspirasi, 10(1), 98-105. https://doi.org/10.35880/inspirasi.v10i1.68

Alwi, M. (2009). Peran Kelompok Kerja Guru (Kkg) Dalam Meningkatkan Profesional Guru Sains Sekolah Dasar Kecamatan Suralaga. Jurnal Educatio, 4(2), 101-107.

Anugrahana, A. (2020). Hambatan, Solusi dan Harapan: Pembelajaran Daring Selama Masa Pandemi Covid-19 Oleh Guru Sekolah Dasar. Scholaria: Jurnal Pendidikan Dan Kebudayaan, 10(3), 282-289. https://doi.org/10.24246/j.js.2020.v10.i3.p282-289

Aspandi. (2020). Pengawas Pai Monitoring Implementasi Protokol Kesehatan Covid-19 Di Sekolah Binaan. Journal.Iaisambas.Ac.Id, VI(2).

Chadijah, C. (2019). Supervisi Akademik Pengawas Sekolah dalam Meningkatkan Etos Kerja Mandiri Guru SD Kota Lhokseumawe. Jurnal Serambi Akademica: Jurnal Pendidikan, Sains, Dan Humaniora, 7(3).

Dakhi, Y. (2016). Implementasi POAC terhadap Kegiatan Organisasi dalam Mencapai Tujuan Tertentu. Jurnal Warta, 53(9), 1679-1699. https://media.neliti.com/media/publications/290701-implementasipoac-terhadap-kegiatan-orga-bdca8ea0.pdf

Darmadji, A. (2003). Menyertakan Masyarakat dalam Proses Pengawasan Sekolah. Jurnal Pendidikan Islam, 8(6), 62-72. http://ahmaddarmadji.staff.uii.ac.id/files/2013/02/darmadjimenyertakan-masyarakat-dalam-pengawasan.pdf

Fadilla, A. N., Relawati, A. S., \& Ratnaningsih, N. (2021). Jurnal jendela pendidikan. 01(02), 48-60. https://www.ejournal.jendelaedukasi.id/ index.php/JJP/article/view/6/8

Guntoro, G. (2020). Supervisi Pengawas dan Kepemimpinan Kepala Sekolah sebagai Stimulus dalam Meningkatkan Kinerja Guru. Jurnal Ilmiah Iqra', 14(1). https://doi.org/10.30984/jii.v14i1.1100

Hadi, A., \& Nasuka, M. (2019). Meningkatkan Kinerja Guru Pada Ma Nu Banat 
Management of Peer Supervision in Improving Teacher 'S Performance on Ma Nu Banat Kudus. 07(2), 51-63.

Han, L., Zhang, S., Ma, P., \& Gao, Y. (2019). Management Control in International Joint Ventures in the Infrastructure Sector. Journal of Management in Engineering, 35(1). https://doi.org/10.1061/(asce)me.1943-5479.0000665

Hazli, H., \& Saputra, R. R. (2019). Analisis Pengaruh Supervisi Pengawas Dan Supervisi Kepala Sekolah Terhadap Kinerja Guru Di Madrasah Ibtidaiyah Kecamatan Sukau Lampung Barat. Publikasi Pendidikan, 9(1). https://doi.org/10.26858/publikan.v9i1.8002

Kirsch, L. J. (1996). The Management of Complex Tasks in Organizations: Controlling the Systems Development Process. Organization Science, 7(1). https://doi.org/10.1287/orsc.7.1.1

Kurnia Utama, Suryawati, D., Administrasi, J. I., Ilmu, F., Politik, I., \& Unej, U. J. (2014). Pengaruh Pengawasan Melekat Terhadap Efektifitas Kinerja Tenaga Kependidikan Di SMP Negeri 9 Jember ( The Effect of Inherent Supervision on the Effectiveness of Educational Personnel Performance at SMP Negeri 9 Jember ). https://bit.ly/3Hn4sCM

Liu, S., \& Wang, L. (2016). Influence of managerial control on performance in medical information system projects: The moderating role of the organizational environment and team risks. International Journal of Project Management, $34(1)$. https://doi.org/10.1016/j.ijproman.2015.10.003

LPPKSPS, K. (2020). Panduan Kerja Pengawas Sekolah Di Masa Pandemi Covid - 19. LPPKSPS Kemendikbud, 1.

Messi, M., Anggita Sari, W., Anggita Sari, W., Murniyati, M., \& Murniyati, M. (2018). Pelaksanaan Supervisi Akademik Pengawas Sekolah Sebagai Upaya Peningkatan Profesionalisme Guru. JMKSP (Jurnal Manajemen, Kepemimpinan, Dan Supervisi Pendidikan), 3(1). https://doi.org/10.31851/jmksp.v3i1.1583 
Miles, M.B., \& Huberman, A.M. (1992). Analisis data kualitatif. (Trans. Tjetjep Rohendi Rohidi). Jakarta: UI Press.

Modo, P. S. (2020). Supervisi Akademik Pengawas Sekolah Pada Sekolah Dasar di Daerah Terluar, Terdepan dan Tertinggal (3T). Media $\begin{array}{lll}\text { Manajemen } \quad \text { Pendidikan, } & 400 .\end{array}$ https://doi.org/10.30738/mmp.v2i3.6779

Nana, Sudjana., 2009. Proposal Penelitian di Perguruan Tinggi. Bandung: Sinar Baru Algesindo.

Nasional, U. S. P. (1982). Introduction and Aim of the Study. Acta Pædiatrica, 71, 6-6. https://doi.org/10.1111/j.1651-2227.1982.tb08455.x

Nurfatah, N., \& Rahmad, N. (2018). Pelaksanaan Supervisi Oleh Kepala Sekolah dan Pengawas Sekolah. JMKSP (Jurnal Manajemen, Kepemimpinan, Dan Supervisi Pendidikan), 3(1). https://doi.org/10.31851/jmksp.v3i1.1585

Nurmayani, N. (2014). Pengawasan Penyelenggaraan Dana Bantuan Operasional Sekolah di Madrasah Ibtidaiyah Negeri Sukarame. FIAT JUSTISIA:Jurnal Ilmu Hukum, 6(3). https://doi.org/10.25041/fiatjustisia.v6no3.82

Oghuvbu, E. P. (2007). Determinants of Effective and Ineffective Supervision in Schools: Teachers Perspectives. Online Submission. http://eric.ed.gov/?q=effective+instructional+supervision\&ft=on\&ff1=d tySince_2006\&id=ED496263

Olivia, Peter, F., 1984. Supervision For Today's School. New York: Longman. Rahmah, S. (2018). Pengawas Sekolah Penentu Kualitas Pendidikan. Jurnal Tarbiyah, 25(2). https://doi.org/10.30829/tar.v25i2.378

Ramadhan, A. (2017). Pengaruh Pelaksanaan Supervisi Akademik Pengawas Sekolah Dan Supervisi Kepala Sekolah Terhadap Kinerja Guru SMK Negeri Di Kabupaten Majene. Journal of Educational Science and Technology (EST), 3(2). https://doi.org/10.26858/est.v3i2.3579

Saleh, M. (2021). Upaya Meningkatkan Kinerja Guru Pendidikan Agama Islam 
(PAI) di Masa Pandemi dengan Pembinaan dan Pemantauan Menggunakan Google Forms. AL MA'ARIEF : Jurnal Pendidikan Sosial Dan Budaya, 3(1), 35-45. https://doi.org/10.35905/almaarief.v3i1.1999 Sanisah, S. (2015). Kebijakan Pengelolaan Anggaran Pendidikan Di Kabupaten Lombok Tengah. Jurnal Pendidikan Ekonomi Dan Bisnis (JPEB), 3(1), 101. https://doi.org/10.21009/jpeb.003.1.5

Sarjono, S. (2020). Penerapan Supervisi Akademik Pengawas Guna Meningkatkan Keterampilan Guru Dalam Melaksanakan Program BDR (Belajar Dari Rumah) Selama Masa Pandemi Covid-19 Di Dabin 1 Korwilcam Bidang Pendidikan Kecamatan Sumowono. In WASPADA (Jurnal Wawasan Pengembangan Pendidikan) (Vol. 8, Issue 2).

Sihag, V., \& Rijsdijk, S. A. (2019). Organizational Controls and Performance Outcomes: A Meta-Analytic Assessment and Extension. Journal of Management Studies, 56(1), 91-133. https://doi.org/10.1111/joms.12342

Slameto, S. (2016). Supervisi Pendidikan Oleh Pengawas Sekolah. Kelola: Jurnal Manajemen Pendidikan, 3(2). https://doi.org/10.24246/j.jk.2016.v3.i2.p192-206

Stoner, James A.F., 1996. Manajemen. Edisi Indonesia. Jakarta: Prenhallindo. Sudibyo, B. (2007). Standar Pengawas Sekolah. Permendikbud No 12 Th 2007. Sugiyono, M. (2021). Pelaksanaan Supervisi Akademik Pengawas Sekolah untuk Mengoptimalkan Pembelajaran Jarak Jauh (PJJ) Kunjungan Rumah di Masa Pandemi Covid-19. JIRA: Jurnal Inovasi Dan Riset Akademik, 2(7). https://doi.org/10.47387/jira.v2i7.189

Suhardan, D. (2007). Efektivitas Pengawasan Profesional dalam Meningkatkan Mutu Pembelajaran pada Era Otonomi Daerah. I(I), 57-65.

U-Sayee, C. R., \& Adomako, E. B. (2021). Supervisory practices and challenges senior high school principals face in Greater Monrovia, Liberia: implications for quality education. Heliyon, 7(4), e06895. https://doi.org/10.1016/j.heliyon.2021.e06895. 